\title{
Serum Phosphate Measurement
}

National Cancer Institute

\section{Source}

National Cancer Institute. Serum Phosphate Measurement. NCI Thesaurus. Code

C61028.

A quantitative measurement of the amount of phosphate present in a sample of serum. 